\title{
ALOX15 wt Allele
}

National Cancer Institute

\section{Source}

National Cancer Institute. ALOX15 wt Allele. NCI Thesaurus. Code C50814.

Human ALOX15 wild-type allele is located in the vicinity of 17p13.3 and is approximately $11 \mathrm{~kb}$ in length. This allele, which encodes arachidonate 15-lipoxygenase protein, plays a role in leukotriene biosynthesis. Decreased expression of the ALOX 15 gene is associated with several types of cancer including breast and colorectal cancer. 